\title{
$k w^{\circ}$
}

$X-822$

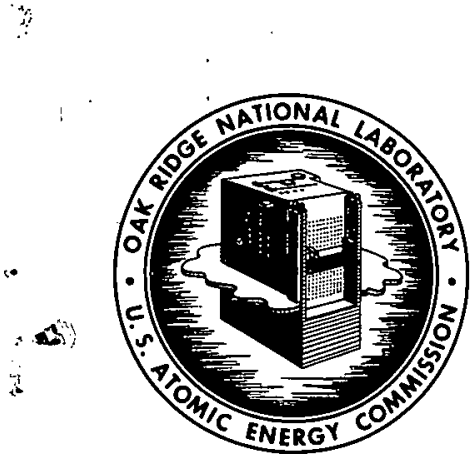

OAK RIDGE NATIONAL LABORATORY

Operated by UNION CARBIDE NUCLEAR. COMPANY

Division of Union Carbide Corporation

UCC

Post Office Box $X$.

Oak Ridge, Tennessee
EXTERNAL TRANSMITTAL

AUTHORI ZED
CENTRAL FILES NUMBER

59-1-90 Rev.

DATE: January 26, 1959

COPY No. $6 /$

SUBJECT: Some Effects of Radiation on Solvent Extraction Processes

TO:

F. L. Culler

FROM: Wallace Davis, Jr。 and Robert M。'Wagner

Presented at : the 135th National Meeting of the A.C.S.

Boston, Massachusetts

April 5-10, 1959

\section{NOTICE}

This document contains information of a preliminary nature and was prepared primarily for internal use at the Oak Ridge National Laboratory. It is subject to revision or correction and therefore does not represent a final report. The information is not to be abstracted, reprinted or otherwise given public dissemination without the approval of the ORNL patent branch, Legal and Information Control Department. 


\section{DISCLAIMER}

This report was prepared as an account of work sponsored by an agency of the United States Government. Neither the United States Government nor any agency Thereof, nor any of their employees, makes any warranty, express or implied, or assumes any legal liability or responsibility for the accuracy, completeness, or usefulness of any information, apparatus, product, or process disclosed, or represents that its use would not infringe privately owned rights. Reference herein to any specific commercial product, process, or service by trade name, trademark, manufacturer, or otherwise does not necessarily constitute or imply its endorsement, recommendation, or favoring by the United States Government or any agency thereof. The views and opinions of authors expressed herein do not necessarily state or reflect those of the United States Government or any agency thereof. 


\section{DISCLAIMER}

Portions of this document may be illegible in electronic image products. Images are produced from the best available original document. 
Some Effects of Radiation on Solvent Extraction Processes

\section{ABSTRACT}

The yield of total acid, $G_{\text {acid, }}$ in the radiolysis of tributyl phosphate-Amsco 125-82 solutions is 2.7 times the electron fraction of TBP, or approximately 2.7 times the weight fraction of TBP, per $100 \mathrm{ev}$. of energy absorbed by the solution. Dibutyl phosphoric acid, DBPA, constitutes about $85 \%$ of the acid. Radiolysis of TBP also results in the conversion of about 0.9 molecules of TBP to a polymer per $100 \mathrm{ev}$ of energy absorbed.

Uranium extraction-stripping tests with an 8 stage spinner column have shown that one mole of uranium is retained in the organic phase during the stripping operation per mole of DBPA added prior to the extraction operation. This is at least twice as much uranium as would be expected on the basis of a compound of the composition $\mathrm{UO}_{2}(\mathrm{DBP})_{2}$. On the basis of a tentative molecular weight of $843 \mathrm{~g} / \mathrm{mole}$, the polymer retains in the organic phase during stripping operations about 1.2 moles. of uranium per mole of polymer added prior to extraction. In addition to polymer and acids, condensed phase radiolysis products include olefins, whose yield, expressed as $G_{c=c}$, or number of double bonds formed per 100 ev of energy absorbed, decreases from ca 4 to 1 as the TBP concentration increases from 4.5 to 100 wt $\%$.

Among newer extractants being examined for use in radiochemical reprocessing, diethyl carbonate, DEC, has been tested for uranium retentiun and fission product decontamination properties. After irradiation to the 400 watt-hr/liter level, the uranium retention by DEC on stripping is decreased, rather than increased. Although $\gamma$-decontamination was adversely affected, $\beta$-decontamination was essentially unaffected by irradiation to this level. 


\section{INTRODUCTION}

After partial burn-up, it is necessary to remove fuels from nuclear reactors in order to remove fission products. The process most widely used to effect this removal is solvent extraction, in which process the fissile or fertile elements (uranium, thorium, plutonium) transfer from an aqueous phase to an organic extractant.solution while the fission products remain in the aqueous solution. Iike other organic compounds, the extractant is subject to decomposition by radiation from the fission products. We shall be concerned with some of the effects of the radiolysis products on the extraction process.

\section{TRIBUTYL PHOSPHATE - AMSCO 125-82 SYSTEMS}

Tributyl phosphate (TBP) in a kerosene-like diluent is the most widely used of the many possible extractants $(4,5,12,13,16)$; its radiolysis has been studied extensively $(1,7,8,9,11,14,15,17)$. Some of the known deleterious effects of radiation on TBP extraction processes are 1) retention of uranium and plutonium in the organic phase during stripping operations, 2) extraction of some of the fission products (particularly $\mathrm{Zr}, \mathrm{Ru}$, and possibly $\left.\mathrm{I}_{2}\right), 3$ ) formation of a very insoluble thorium compound, which has necessitated the addition of a filtration step to the Thorex Process when high burn-up, short decayed fuels are processed, and 4) emulsion formation, which increases phase separation time, thereby decreasing column efficiency.

Neglecting gases, the principal product of the radiolysis of TBP is dibutyl phosphoric acid (DBPA). Monobutyl phosphoric acid (MBPA) and $\mathrm{H}_{3} \mathrm{PO}_{4}$ are formed in considerably smaller quantities. DBPA is known to be one of the principal causes of trouble in radiochemical reprocessing. For example, it forms a solvent-soluble complex with uranium, presumably uranyl dibutyl phosphate; with thorium, on the other hand, it forms a compound that is very insoluble in aqueous or organic phases. The solubility of the compound, probably thorium 
tetra-dibutyl phosphate, in TBP-kerosene solution is less than $0.04 \mathrm{~g} / 1$ iter (17).

DBPA accounts for about $85 \%$ of the total acidic products from the radiolysis of IBP-kerozene solutions. Yield studies, Figure 1, show that

$$
\mathrm{G}_{\text {acid }}=2.7 \mathrm{~F}_{\mathrm{TBP}}^{\mathrm{e}}
$$

where $\mathrm{F}_{\mathrm{TBP}}^{e}$ is the electron fraction of TBP in the kerosene solution. To a close degree of approximation, $F_{\text {TBP }}^{e} \cong W_{T B P}=$ weight fraction of TBP in the solution. If the radiation dose density, $D$, is expressed in terms of watt-hr/liter, then the molarity of the acidic product may be expressed as

$$
\begin{gathered}
M_{\text {acid }}=9.20 \times 10^{-4} \mathrm{DW}_{\mathrm{TBP}} \\
\text { or } \quad \mathrm{W}_{\text {acid }}=9.20 \times 10^{-7} \mathrm{DW}_{\mathrm{TBP}} \frac{(\mathrm{M} \text { Wt of acid) }}{9 \text { solution }}
\end{gathered}
$$

Using $\mathrm{W}_{\mathrm{TBP}}=0.4$, corresponding to the approximately $40 \%$ TBP in Amsco 125-82 used in the Thorex Process first cycle extraction column (5), it can be shown that the thorium compound will start precipitating when the radiation dose exceeds about 0.38 watt-hr/liter.

As Cathers (9) has indicated, deleterious effects are observable when radiation dose densities have increased to 0.1 to 0.5 watt-hr/liter, corresponding, for example, to $7.14 \times 10^{-4}$ to 3.57 to $10^{-3}$ wt $\%$ radiolytic acids (DBPA, MBPA, $\mathrm{H}_{3} \mathrm{PO}_{4}$ ) in TBP-Amsco $125-82$ solutions.

Laboratory studies have been performed to determine the effect of DBPA and radiolytic polymer on uranium distribution coefficients and phase separation times. In these experiments, purified DBPA or polymer isolated from TBP that had been irradiated to 1900 watt-hr/liter were added in known quantities to pure TBP. to the concentrations indicated in Figure 2. The TBP plus addend was then diluted to $25 \% \mathrm{~W} / \mathrm{V}$ in Amsco and contacted with 2 volumes of $2 \mathrm{M} \mathrm{HNO}_{3}-0.2 \mathrm{M} \mathrm{UO}_{2}\left(\mathrm{NO}_{3}\right){ }_{2}$. Data plotted in Figure 2 were obtained with an 8 stage (calibrated) spinner column and express the ratio of uranium in the stripped organic stream to that in the aqueous product stream. The effects of both DBPA and polymer on retention of uranium by the organic phase during stripping 


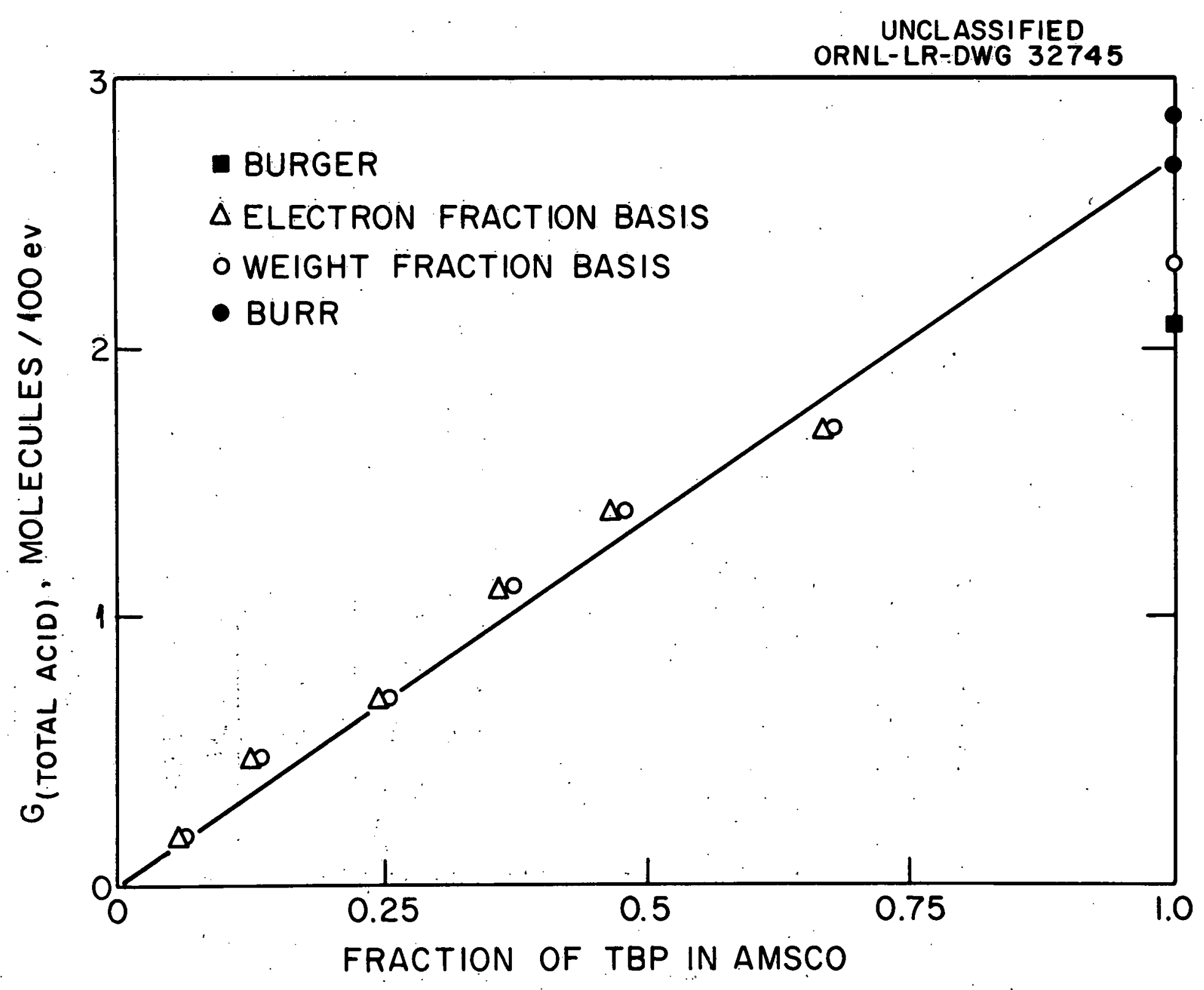

Figure 1: Acid Yield in the Hydrolysis of TBP-Amsco 125-82 Solutions: Dose: $-1.60 \times 10^{13}$ ergs/kg solution (Approx. $400 \mathrm{watt-hr} /$ liter). 

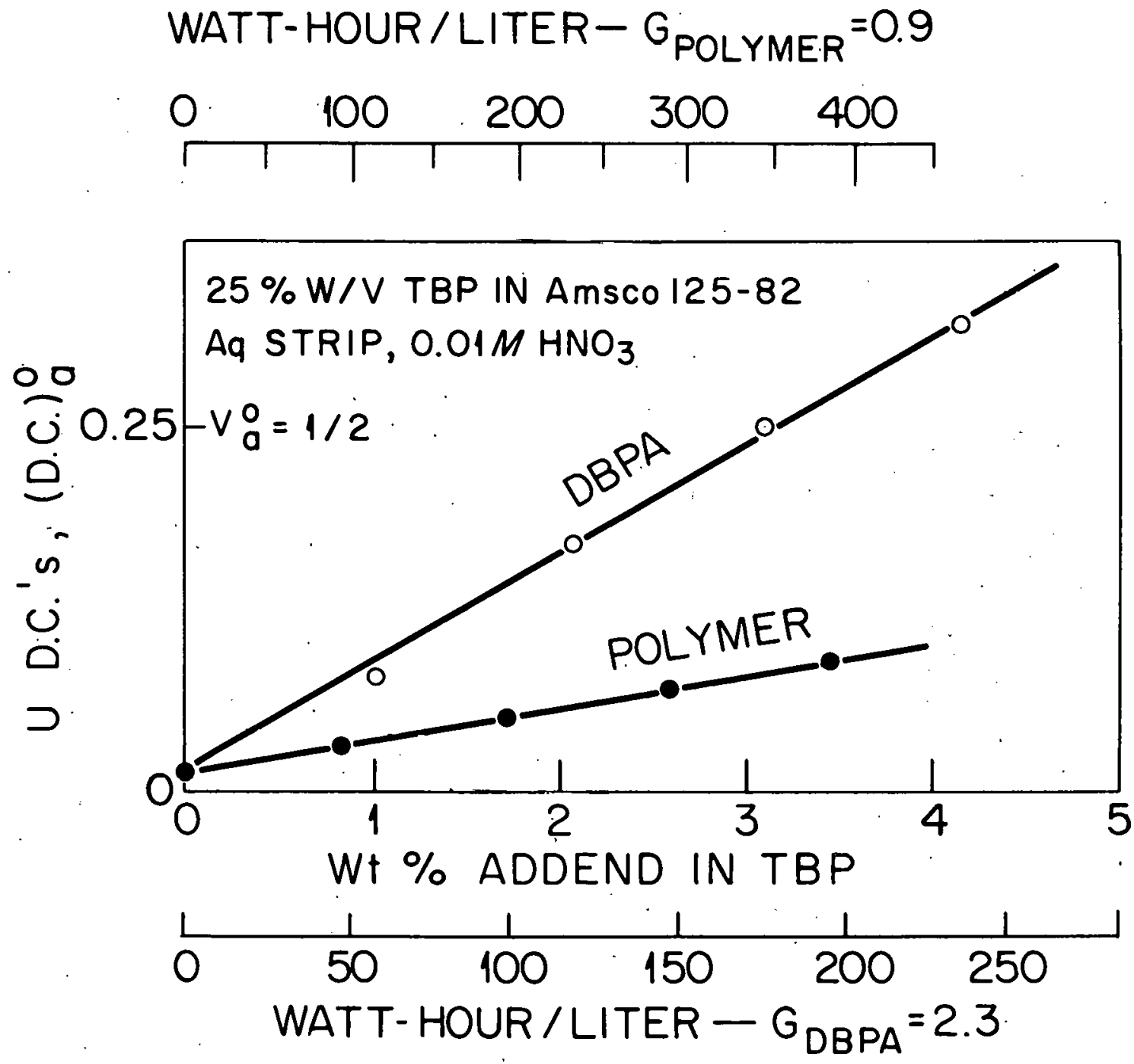

Figure 2: $\quad$ Effect of Dibutyl Phosphoric Acid (DBPA) and Radiolytic Polymer from TBP on Uranium Retention by the Extractant during Stripping Operations. 
are linearly dependent on concentration and, therefore, on dose density. In the dose density correlation, equations similar to 1 and 2 were used, $M_{a c i d}$ in these equations being replaced by $M_{-D B P A}$ or $M_{\text {Polymer }}$ and $G_{\text {acid }}$ by $G_{D B P A}$ or $G_{\text {Polymer }}$. For $G_{D B P A}$ a value of 0.85 acid was used; for $G_{\text {Polymer }}$ (actually the number of molecules of TBP converted to polymer per 100 ev of energy absorbed) an experimental value of 0.9 was used. This was determined from the irradiation of TBP to the 1900 watt-hr/liter level; Burr (8) has reported values of 1.50 and 2.47 . The data of these experiments can be used to calculate the uranium loss due to complexing with DBPA or polymer, wherein pertinent terms are defined as follows.

$X_{f}=$ concentration of uranium in the extraction cycle aqueous feed, $M$; $X_{W}=$ concentration of uranium in the extraction cycle aqueous waste, $M_{\text {; }}$

$Y=$ concentration of uranium in the extraction cycle organic product and stripping cycle organic feed, $\underline{M}$;

$X=$ concentration of uranium in the stripping cycle aqueous product, $M$;

$Y_{W}=$ concentration of uranium in the stripping cycle organic waste, $M$;

$F=$ aqueous extraction cycle feed rate;

$Q$ = organic extraction and stripping cycle flow rates;

$S=$ aqueous stripping cycle flow rate.

From a uranium balance across the spinner column we may write

$$
Y_{W}=\frac{\frac{Q}{S}\left(\frac{Y}{W}\right)}{\frac{Q}{S}\left(\frac{Y}{X}\right)^{\prime}+1}
$$

for the stripping operation in the absence of added DBPA or polymer, and a similar expression for the case of added DBPA or polymer. 4 
With the conditions $X_{f}=0.2 \underline{M},\left(Y_{W} / X\right)$ and $Y$ as listed in Table $1,(Q / S)$ $=0.5$, and $(Q / F)=0.5$, it may be seen that the retention of uranium in the organic phase persists through an 8 stage stripping operation and that the uranium retention is about twice that expected on the basis of a compound $\mathrm{UO}_{2}(\mathrm{DBP})_{2}$. For each mole of $\mathrm{DBPA}$ added to the system prior to extraction, one mole of uranium is retained after 8 stages of stripping.

Table 1. Permanency of the Retention of Uranium by Dibutyl Phosphoric Acid in a 25\% TBP-Amsco 125-82 Solution*

\begin{tabular}{|c|c|c|c|c|c|}
\hline $\begin{array}{l}\text { Conen. } \\
\text { of DBPA, } \\
\underline{M}\end{array}$ & $\begin{array}{l}\text { Uranium } \\
\text { Distribution } \\
\text { Coefficient, } \\
\frac{\mathrm{Y}_{\mathrm{w}}}{\mathrm{X}}=\mathrm{E}_{\mathrm{a}}^{\circ}\end{array}$ & $\begin{array}{l}\text { Equivalent } \\
\text { Radiation Dose, } \\
\text { Watt-hr/liter }\end{array}$ & $\begin{array}{l}\text { Organic } \\
\text { Phase U } \\
\text { Concn., Y, } \\
\underline{M}\end{array}$ & $\begin{array}{c}\text { U-Retention } \\
\text { Due to DBPA, } \\
\text { M }\end{array}$ & $\begin{array}{l}\text { Moles U Lost } \\
\text { Per Initial } \\
\text { Mole DBPA. }\end{array}$ \\
\hline 0.00000 & 0.011 & 0 & 0.354 & 0.0000 & 0.00 \\
\hline 0.01225 & 0.08 & 63 & 0.391 & 0.0131 & 1.07 \\
\hline 0.02450 & 0.17 & 125 & 0.391 & 0.0287 & 1.17 \\
\hline 0.03675 & 0.25 & 188 & 0.391 & 0.0415 & 1.13 \\
\hline 0.04900 & 0.32 & 251 & 0.391 & 0.0520 & 1.06 \\
\hline
\end{tabular}

*See Text for experimental conditions.

Table 2. Permanency of the Retention of Uranium by Polymer Produced During Irradiation of TBP in a 25\% TBP-Amsco 125-82 Solution*

\begin{tabular}{|c|c|c|c|c|c|}
\hline $\begin{array}{l}\text { Concn. of } \\
\text { Polymer, ** } \\
\text { M }\end{array}$ & $\begin{array}{l}\text { Uranium } \\
\text { Distribution } \\
\text { Coefficient, } \\
\frac{\mathrm{Y}_{\mathrm{W}}}{\mathrm{X}}=\mathrm{E}_{\mathrm{a}}^{\mathrm{O}}\end{array}$ & $\begin{array}{l}\text { Equivalent } \\
\text { Radiation Dose, } \\
\text { Watt-hr/liter }\end{array}$ & $\begin{array}{l}\text { Organic } \\
\text { Phase U } \\
\text { Conen., Y, } \\
\text { M }\end{array}$ & $\begin{array}{c}\text { U-Retention } \\
\text { Due to Polymer, } \\
\underline{M}\end{array}$ & $\begin{array}{l}\text { Moles U Lost } \\
\text { Pèr Mole of } \\
\text { TBP Initially } \\
\text { Present as } \\
\text { Polymer** }\end{array}$ \\
\hline 0.00000 & 0.011 & 0 & 0.354 & 0.00000 & 0.000 \\
\hline 0.00813 & 0.03 & 106 & 0.340 & 0.00309 & 0.380 \\
\hline 0.01626 & 0.05 & 212 & 0.340 & 0.00636 & 0.391 \\
\hline 0.02439 & 0.07 & 318 & 0.340 & 0.00957 & 0.392 \\
\hline 0.03252 & 0.09 & 424 & 0.340 & 0.01271 & 0.391 \\
\hline
\end{tabular}

* See Text for experimental conditions.

** The concentration of polymer is expressed in units of TBP since the only molecular weight determination, $843 \mathrm{~g} / \mathrm{mole}$, is very tentative. Approximately 0.9 molecules of TBP are converted to polymer per $100 \mathrm{ev}$ of energy absorbed. 
The quantitative correlation of uranium retention with radiolytic polymer concentration is given in Table 2. Here agin, the retention is large, even after an 8 stage stripping operation, and corresponds to ca 0.4 moles of uranium per molecule of TBP contained in the polymer. If the tentative, average molecular weight of polymer is used, namely $843 \mathrm{~g} / \mathrm{mole}$, retention corresponds to ca 1.2 moles of uranium per mole of polymer.....

Further information on the effects of radiation on uranium losses in TBP-Amsco solvent extraction were obtained from an experiment in which 0.37 volume of an aqueous solution of $1.3 \mathrm{M} \mathrm{UO}_{2}\left(\mathrm{NO}_{3}\right)_{2}-1.84 \mathrm{M} \mathrm{HNO}_{3}$ was stirred with 1 volume of 30\% TBP in Amsco 125-82 while being irradiated to the 125 watt-hr/liter level in a $10 \mathrm{kllocurie}$ cobalt-60 source. After stripping the organic phase with four 0.32 volume and four 0.8 volume of $0.01 \mathrm{M}^{\mathrm{HNO}}{ }_{3}$, the uranium content had decreased to an average of $3 \mathrm{~g} /$ liter; $1.0 ., 2.7 \%$ of the uranium remained in the organic phase.

It should be noted that some of the fission product elements may compete favorably with uranium in forming complexes or compounds with DBPA or radiolytic polymer. Such competition can greatly reduce the extent of decontamination.

Formation of olefinic compounds in irradiated TBP-hydrocarbon solutions has been recognized for some time $(9)$. Recently, yields for double bond formation have been calculated from measurements of iodine numbers. . A. summary of results is given in Table 3. It is apparent that radiolysis of TBP-Amsco 125-82 solutions yields an ample quantity of unsaturated hydrocarbon with which radioactive iodine may react, thereby resulting in solvent contamination that can be removed only with difficulty.

Table 3. Olefin Formation During Radiolysis of TBP-Amsco 125-82 Solutions

\begin{tabular}{cccc}
\hline $\begin{array}{c}\text { Solution } \\
\begin{array}{c}\text { Composition, } \\
\% \text { W/V }\end{array}\end{array}$ & $\begin{array}{c}\text { Dose } \\
\text { Watt-hr/liter }\end{array}$ & $\begin{array}{l}\text { Increase in } \\
I_{2} \text { Number }\end{array}$ & $G_{c=c}$ \\
\hline 4.5 & 400 & 14.2 & 3.37 \\
10 & 400 & 13.4 & 3.17 \\
20 & 400 & 11.4 & 2.70 \\
30 & 400 & 11.4 & 2.70 \\
45 & 400 & 10.5 & 2.49 \\
60 & 400 & 8.1 & 1.92 \\
100 & 400 & 4.2 & 1.00 \\
15 & 200 & 8.6 & 4.08 \\
25 & 200 & 7.7 & 3.65. \\
\hline
\end{tabular}


OTHER EXTRACTANTS

Many organic compounds, such as phosphates, phosphonates, phosphinates, phosphine oxides, primary -, secondary -, and tertiary amines, have been tested for possible utility in extracting uranium from sulfate ore leach liquors $(2,3,6,10)$. Some of these compounds have been examined as extractants in n1tric acid systems employing carbon tetrachloride as diluent (6). At present, we are trying to determine the effects of radiation on uranium retention and fission product decontamination by typical examples of these various classes of extractants. One of these examples is diethyl carbonate, DEC.

Diethyl carbonate is a very weak complexing agent for uranium. Extraction requires highly salted, but only modestly acidic feed solution. Good extraction of uranium from 1.5 to $1.75 \mathrm{M} \mathrm{Al}\left(\mathrm{HO}_{3}\right){ }_{3}$ and $1 \mathrm{M} \mathrm{HNO}_{3}$ can be obtained. These conditions provide uranium distribution coefficients. D.C. ${ }_{a}^{\circ}$ (organic phase concentration/aqueous phase concentration), of approximately 2 if the uranium concentration in the feed is in the order of $0.2 \mathrm{M}$.

A sample of DEC irradiated to the 400 watt-hr/liter level and an unirradiated control. sample were contacted with equal volumes of an aqueous feed containing $0.172 \mathrm{M} \mathrm{UO}_{2}\left(\mathrm{NO}_{3}\right)_{2}, 1.57 \mathrm{M} \mathrm{Al}_{3}\left(\mathrm{NO}_{3}\right) 3^{3}: 0.99 \mathrm{M} \mathrm{HNO}_{3}$, and the fission products (F.P.) shown in Table 6 . Values of uranium D.C. $\frac{0}{a}$, Table 4, show that the irradiated DEC may have extracted uranium somewhat better than did the unirradiated sample. Measurements of radioactivity showed the irradiated DEC to extract less B-activity but more $\gamma$-activity than the unirradiated control.

The two DEC solutions, irradiated and unirradiated, were scrubbed to determine whether the fission products could easily be back-washed into the aqueous phase. This back washing occurred to a very large extent in both cases. The scrub solution had a composition nearly the same as that of the aqueous solution from the extraction operation, namely $0.060 \mathrm{M}$ $\mathrm{UO}_{2}\left(\mathrm{NO}_{3}\right)_{2}, 1.87 \mathrm{M} \mathrm{AI}\left(\mathrm{NO}_{3}\right)_{3}, 0.56 \mathrm{M} \mathrm{HNO}_{3}$ (see Table 4 for comparison). As a result, the compositions of irradiated and unirradiated DEC changed only slightly during scrubbing, except for fission product activity. 
Comparison of stripping data, Table 5, shows that the irradiated DEC retained less uranium than did unirradiated DEC." This is just the opposite of the situation that prevails with TBP-kerosene diluent solutions wherein the radiolytically formed DBPA holds uranium in the extractant phase during stripping operations.

In general, radiolysis products do not have a very deleterious effect on extraction of uranium and its separation from fission products (Table 4, 5, 6), except for decontamination from $\gamma$-active elements. At the present time we can say that DEC is superior to TBP-kerosene systems from the standpoint of uranium retention, but we do not yet have a good control for comparison of decontamination of fission products. This Is due, primarily to use of batch contacting in the experiments with DEC whereas work with TBP-kerosene solutions has been performed with multistage, countercurrent equipment.

Table 4. Experimental Conditions, Diethyl Carbonate Extraction Test ${ }^{*}$

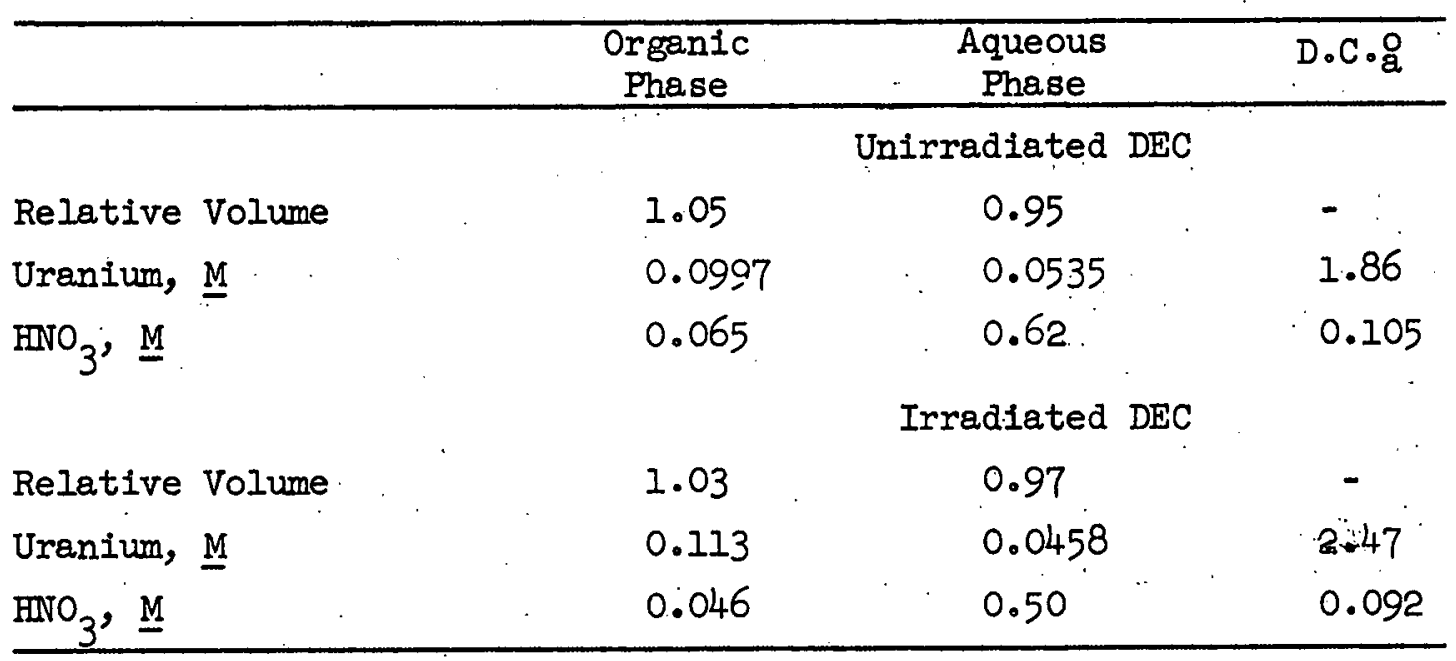

*Feed: $0.172 \mathrm{MUO}_{2}\left(\mathrm{NO}_{3}\right)_{2} ; 1.57 \mathrm{M} \mathrm{Al}\left(\mathrm{NO}_{3}\right)_{3} ; 0.99 \mathrm{M} \mathrm{HNO}_{3}$; Fission Products as in Table 6; Relative Volume =. 1 Extractant: DEC; Relative Volume $=1$ 
Table 5. Experimental Conditions, Diethyl Carbonate Stripping Test*

\begin{tabular}{|c|c|c|c|c|}
\hline . & $\begin{array}{l}\text { Organic } \\
\text { Phase }\end{array}$ & $\begin{array}{c}\text { Aqueous } \\
\text { Phase }\end{array}$ & & $\mathrm{D} \cdot \mathrm{C} \cdot \mathrm{O}$ \\
\hline & \multicolumn{4}{|c|}{ Unirradiated DEC } \\
\hline Relative Volume & 1 & 1 & & - \\
\hline Uranium, M & $(0.0174)^{* *}$ & 0.0972 & & 0.18 \\
\hline \multirow[t]{2}{*}{$\mathrm{FNO}_{3} ; \underline{\mathrm{M}}$} & - & 0.49 & & - \\
\hline & & Irradiated & $\mathrm{DEC}$ & \\
\hline Relative Volume & 1 & 1 & & - \\
\hline Uranium, M & $(0.00955)^{* *}$ & 0.1055 & & 0.0905 \\
\hline $\mathrm{HNO}_{3}, \underline{\mathrm{M}}$ & - & 0.52 & & - \\
\hline
\end{tabular}

* Feed: Organic phase from scrubbing operation; Relative Volume = I;

Strip: $0.01 \mathrm{M} \mathrm{HNO}_{3}$; Relative Volume $=1$

* Calculated by difference on basis of feed and product compositions.

Table 6. Effects of Radiation on Fission Product Distribution During Extraction with Diethyl Carbonate

\begin{tabular}{|c|c|c|c|c|c|}
\hline$\cdot$ & $\begin{array}{c}\text { Gross } \\
B\end{array}$ & $\begin{array}{c}\text { Gross } \\
y \\
\end{array}$ & $\begin{array}{c}\mathrm{Zr}-\mathrm{Nb} \\
y\end{array}$ & $\dot{\mathrm{Ru}}^{\mathrm{y}}$ & $\begin{array}{c}\operatorname{TRE}^{* *} \\
B \\
\end{array}$ \\
\hline $\begin{array}{l}\text { Feed, (c/min-mg U) } \times 10^{-4} \\
\text { Dist. Coeff. on Extraction }\end{array}$ & 4.63 & 2.93 & 2.14 & 0.249 & 3.20 \\
\hline$\left(\right.$ D.C. $\left.{ }_{a}^{0}\right) \times 10^{2}$ : Unirradiated: & 2.53 & $2 \times 30$ & 2.64 & 4.70 & 2.84 \\
\hline : Irradiated & 1.04 & $5 \cdot 38$ & 6.36 & 10.4 & 0.017 \\
\hline
\end{tabular}

Decontamination Factor.

$\begin{array}{lrrrrr}\text { : Unirradiated } & 700 & 370 & 315 & 170 & 1060 \\ \text { : Irradiated } & 520 & 85 & 76 & 22 & 1080\end{array}$

* See text and Table 4 and 5 for conditions.

* Total rare earth elements.

\section{ACKNOWLEDGEMENTS}

A number of people at the Oak Ridge National Laboratory and Stanford Research Institute have contributed to the experimental results reported in this paper. Particular thanks are due to J. R. Flanary, J. H. Goode, and L. H: Towle. The various analyses associated with this work were performed by E. I. Wyatt, W. R. Laing, W. E. Wilson, and W. C. Crawford. 


\section{BIBLIOGRAPHY}

1. Baldwin, W. H., Acid Formation in the Radiolysis of Phosphorus Esters, Union Carbide Nuclear Company, Oak Ridge National Laboratory, April 3 , 1957 (ORNL CF-57-4-9).

2. Blake, C.A., et al., Solvent Extraction of Uranium and Other Metals by Acidic and Neutral Organophosphorus Compounds, Proc. 2nd Internat' I Conf. on Peaceful Uses of Atomlc Energy, Geneva; 1958, Paper 1550, Vol. 28, p. 000, U。 No, New York, In press.

3. Brown, K. B., et al., Solvent Extraction Processing of Uranlum and Thorium Ores, Proc. 2nd Internat'l Conf. on Peaceful Uses of Atomic Energy, Geneva, 1958, Paper 509, Vol. 3, p. 000, U. N., New York, 1958.

4. Bruce, F. R., The Behavior of Fission Products in Solvent Extraction Processes, in "Process Chemistry;" Ch. 4-3, Progress in Nuclear Energy, Series III, McGraw-Hill, New York, 1956.

5. Bruce, F. R., The Thorex Process in Book 1, p. 180, Symposium on the Reprocessing of Irradiated Fuels, Brussels, 1957, TID-7534, Technical Information Service, Oak Ridge, Tennessee.

6. Burger, I. L. Uranium and Plutonium Extraction by Organophosphorus Compounds, J. Phys. Chem., 62, 590 (1958).

7. Burger, L. L. and McClanahan; E. D., Tributyl Phosphate and Its Diluent Systems, Ind. Eng. Chem. 50, 153 (1958).

8. Burr, J. G., The Radiolysis of Tributyl Phosphate, Radiation Research 8, $214(1958)$.

9. Cathers, G. I., Radiation Damage to Radiochemical Processing Reagents in "Process Chemistry," Ch. 2-4, Progress in Nuclear Energy, Series III, McGraw-Hill, New York, 1956.

10. Coleman, C.F., et al., Amine Salts as Solvent Extraction Reagents for Uranium and Other Metals, Proc. 2nd Internat'l Conf. on Peaceful Uses of Atomic Energy, Geneva, 1958, Paper 510, Vol. 28, p. 000, U. N., New York, In press.

11. Cooper, V. R., and Walling, M. T., Jr., Aqueous Processes for Separation and Decontamination of Irradiated Fuels, Proc. 2nd Internat'l Conf. on Peaceful Uses of Atomic Energy, Geneva, 1958, Paper 2409, Vol. 17, p. $000, \mathrm{U} . \mathbb{N}$. , New York, In press。

12. Flanary, J. R., A Solvent Extraction Process for the Separation of Uranium and Plutonium from Fission Products by Tributyl Phosphate, in "Process Chemistry," Ch. 5-3, Progress in Nuclear Energy, Serles III, McGraw-Hill, New York, 1956. 
13. Fletcher, J. M., Chemical Princlples in the Separation of. Fission Products from Uranium and PIutonium by Solvent Extraction, ibid, Ch. 4-I.

14. Goode, J. H., How Radiation Affects Organics in Solvent Extraction of Fuel, Nucleonics, 15, 68 (1957).

15. Goode, J. H., Radiation Damage to TBP and Diluents Covering Perlod October-December, 1956, Union Carbide Nuclear Company, Oak Ridge National Laboratory, May 7, 1957 (ORNL-2287).

16. McKay, H. A. C., and Fletcher, J. M., Chemical Studies for the Separation of U233 from Irradiated Thortum, in "Process Chemistry;" Ch. 4-4, Progress in Nuclear Energy, Series III, McGraw-Hill, New York, 1956.

17. Wagner, R. M. and Towle, L. H., Radiation Stabllity of Organic Liquids, Semi-Annual Report, No. F, Subcontract 1081 between Stanford Research Institute and the Chemikal. Technology Division," Oak Ridge National Laboratory, January y 5959. 
INIERNAL DISTR IBUTION

1. F. L. Culler

2. R. E. Blanco

3. J.C. Bresee

4. K. B. Brown

5. F. R. Bruce

6. W. K. Eister

7. H. E。 Goeller

8. D. E. Ferguson

9. A. T. Gresky

10. W. H. Lewis

11. R. B. Lindauer

12. W. T. McDuffee

13. R. H. Rainey

14-16. E. M. Shank

17. M. J. Skinner

18. W. E. Unger

19. R. M. Wagner

20-21. Central Research Library

22. Document Reference Section

23-32. Laboratory Records

33. Laboratory Records $=R C$

34-48. W, Davis, Jr.

\section{EXTERNAL DISTRIBUTION}

49-50. F. L. Cuthbert, FMPC

51-52. I. G. Dillon, ANL

53-54. O. F. Hill, HAPO

55-56. B. Manowitz, BNL

57-58. V. R. Thayer, du Pont

59-60. M. E. Weech, ICPP

61-75. TISE 